\title{
Self-injury and suicide attempt among the elderly population in the city of São Paulo
}

\author{
Autoagressão e tentativa de suicídio entre a \\ população idosa da cidade de São Paulo \\ Jane de Eston Armond', Rodrigo de Eston Armond', Tatiana Cristina Pereira', Cléo Chinaia', \\ Thiago Leão Vendramini², Cintia Leci Rodrigues ${ }^{3}$
}

\begin{abstract}
Objective: In this perspective, the present research aims to describe the reports of self-injury and suicide attempt among the elderly population living in the city of São Paulo. Methods: This is a descriptive, quantitative approach based on Violence and Accidents Surveillance Information System (SIVVA) of the city of São Paulo. In the selection of notifications, it was included the ones related to self-injury and attempted suicide against men and women, with age group between 60 and over, from January to December 2014 in the city of São Paulo, Southeastern Region of Brazil. Results: During 2014, 93 cases of self-injury and attempted suicide were reported among elderly people living in the city of São Paulo. The main instruments used by the elderly population in the analyzed period were poisoning (41.9\%), other means (34.4\%), cold weapon (15.1\%), high precipitation places (4.3\%), hanging or suffocation (3.2\%), and firearm (1.1\%). Conclusion: From the results of this study it was possible to characterize some specific aspects related to self-injury and suicide attempt among elderly in the evaluated population. Therefore, developing a strategy to promote effective prevention actions and offer specialized services to most risk groups (brown races, people with lower levels of education, and males).
\end{abstract}

\section{Keywords}

Aged, suicide, attempted, mental health, prevention and control.

\section{RESUMO}

Objetivo: Nesta perspectiva, a presente pesquisa tem como objetivo descrever os casos de autoagressão e tentativa de suicídio entre a população idosa residente na cidade de São Paulo. Métodos: Esta é uma abordagem descritiva e quantitativa baseada no Sistema de Informação para Vigilância de Violências e Acidentes (SIVVA) da cidade de São Paulo. Na seleção das notificações, foram incluídos os relacionados à autoagressão e à tentativa de suicídio contra homens e mulheres, com faixa etária entre 60 e mais, de janeiro a dezembro de 2014 na cidade de São Paulo, Região Sudeste do Brasil. Resultados: Durante o ano de 2014, 93 casos de autolesão e tentativa de suicídio foram notificados em pessoas idosas residentes na cidade de São Paulo. Os principais instrumentos utilizados pela população idosa no período analisado foram envenenamentos (41,9\%), outros meios (34,4\%), arma branca $(15,1 \%)$, locais de alta precipitação (4,3\%), suspensão ou sufocação $(3,2 \%)$ e arma de fogo $(1,1 \%)$.

1 University of Santo Amaro (Unisa), Health Sciences. 2 Psychologist. 


\section{Palavras-chave}

Idosos, tentativa de suicídio, saúde mental, prevenção e controle.
Conclusão: Com os resultados deste estudo, foi possível caracterizar alguns aspectos específicos relacionados a autoagressão e tentativa de suicídio entre os idosos na população estudada. Portanto, faz-se necessário desenvolver uma estratégia para promover ações de prevenção eficazes e oferecer serviços especializados para a maioria dos grupos de risco (raça parda, pessoas com níveis mais baixos de educação e homens).

\section{INTRODUCTION}

Several regions of the world have undergone a process of demographic transition in which populations, typically young and adults have gradually become older'. This transition has consequences for the health systems and society, for one of the characteristics that makes the epidemiological profile of the elderly particular is the predominance of chronic diseases, of gradual progression and high capacity to affect and reduce the autonomy, and independence of the individual. At some point in the illness, the elderly will seek for the health service and in general, the use is more prolonged than in other stages of life ${ }^{1,2}$.

Aging is an inherent process of the life cycle, with changes that can concentrate or spread on physical, financial, psychological, emotional, and structural aspects. When there is no multidimensional support at this stage of life, the elderly often perceive themselves as useless, with no future prospects, and thus become more vulnerable to suicide? .

According to Özer et al., in relation to violence the World Health Organization (WHO) provides a useful model for understanding the patterns of its occurrence in the world, in the daily lives of individuals, families and communities. According to this model, violence is branched into three broad categories: self-directed violence or self-injury; interpersonal violence; collective violence ${ }^{4}$.

Concerning self-injury, there are two types by the same model: suicidal behavior involving suicide attempts and suicidal thoughts or deliberate self-injury, and self-abuse, including acts of self-mutilation ${ }^{4}$.

Suicide is a complex universal human phenomenon, and represents a major public health problem throughout the world ${ }^{4,5}$. According to Vidal et al. ${ }^{5}$, the risk of suicide increases according to the number of attempts and is associated with shorter time intervals amongst them ${ }^{5}$.

The population over 60 is the fastest growing in Brazil and most part of the world, which justifies a careful look at the social and health problems that affect them ${ }^{6}$. Although the increase in suicide rates has been acknowledged, ideations and attempts associated with the process of aging, there are still few studies deepened on this subject, particularly in Brazil. The literature shows the connection of the social and family context with the cases of suicide, as well as the impact of these cases in the families and in the social circle ${ }^{3,6,7}$.
In this perspective, the present research aims to describe the reports of self-injury and suicide attempt among the elderly population living in the city of São Paulo.

\section{METHODS}

This is a descriptive, quantitative approach based on Violence and Accidents Surveillance Information System of the city of São Paulo (SIVA), which is fed by reports and investigations of violence cases and Accidents that appear in the list of diseases, according to the Ordinance $n^{\circ} 1328 / 078$ of the Municipal Health Department of the city of São Paulo8.

Data collection took place in November 2016, based on queries to the SIWA electronic address (http://tabnet.saude. prefeitura.sp.gov.br/cgi/deftohtm3.exe?secretarias/saude/ TABNET/SIWA/autoagr/AUTOAGR.DEF) ${ }^{9}$. Through SIVA were collected information contained in self-injury and suicide attempt, and the elderly population (individuals aged 60 years old or over) was selected.

In the selection of notifications, it was included the ones related to self-injury and attempted suicide against men and women, with age group between 60 and over, from January to December 2014 in the city of São Paulo, Southeastern Region of Brazil.

Researches on SIVA website generated condensed information files per year, which were imported into Excel spreadsheets for further analysis.

For the variables considered in the present study, a consolidated study was performed adding up manually the quantitative obtained from the studied period.

For the characterization of self-injury and suicide attempt the variables that make up the notification form were: residence region (Center, East, North, Southeast, South and West), age group (years), gender (male and female), instrument used (drowning, weapon, firearm, hanging or suffocation, intoxication/poisoning, precipitation of high place, and other means), place of occurrence (residence, public road, long-term institution, workplace), time of occurrence, diagnosis of injury, race/color, education, alcohol and drug use, evolution of the case.

The study was carried out exclusively with data from public access, so it was not necessary to evaluate the research ethics committee in human research, according to Resolution of the National Health Council (CNS 446/12). 


\section{RESULTS}

During 2014, 93 cases of self-injury and attempted suicide were reported among elderly people living in the city of São Paulo.

The city of São Paulo is divided into six regions by the coordinating body of resident health, as shown in Figure 1. The Southern Region (40.9\%), followed by the North (19.4\%), East $(12.9 \%)$, West (7.5\%), Southeast (4.3\%), Center (1.1\%), and $14.0 \%$ of reported cases had the residence address of the elderly ignored.

Table 1. Notification of self-injury and attempted suicide among the elderly in the city of São Paulo according to their age group and sex, year 2014

\begin{tabular}{lcccc}
\hline Age Group & Female & $\mathbf{f}(\%)$ & Male & $\mathbf{f}(\%)$ \\
\hline 60 a 64 years & 11 & 32.4 & 23 & 39.0 \\
65 a 69 years & 11 & 32.4 & 14 & 23.7 \\
70 a 74 years & 4 & 11.8 & 10 & 16.9 \\
75 a 79 years & 3 & 8.8 & 8 & 13.6 \\
80 a 84 years & 3 & 8.8 & 2 & 3.4 \\
85 a 89 years & 2 & 5.9 & 1 & 1.7 \\
90 years and + & 0 & 0.0 & 1 & 1.7 \\
Total & 34 & 100.0 & 59 & 100.0 \\
\hline
\end{tabular}

As shown in Table 1, self-injury and suicide attempt occurred mainly among elderly men, aged between 60 and 69 years.

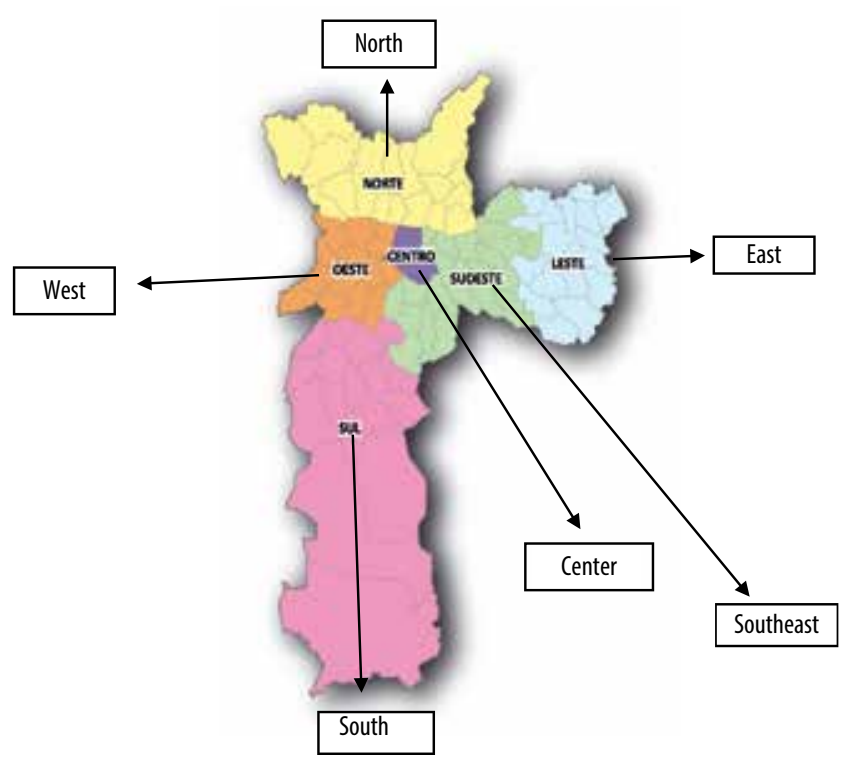

Figure 1. Map of the City of São Paulo.

The main instruments used by the elderly population in the analyzed period were poisoning (41.9\%), other means (34.4\%), cold weapon (15.1\%), high precipitation places (4.3\%), hanging or suffocation (3.2\%), and firearm (1.1\%).
In relation to the instrument used in self-injury and suicide attempt, intoxication/poisoning was the most frequent in both sexes. High precipitation nature incidents occurred mainly among elderly male (Figure 2). The main agents of intoxication were alcoholic beverage (28.2\%), poison (15.4\%), and medications (28.2\%). Among the drugs, the most reported were diazepam and clonazepam.

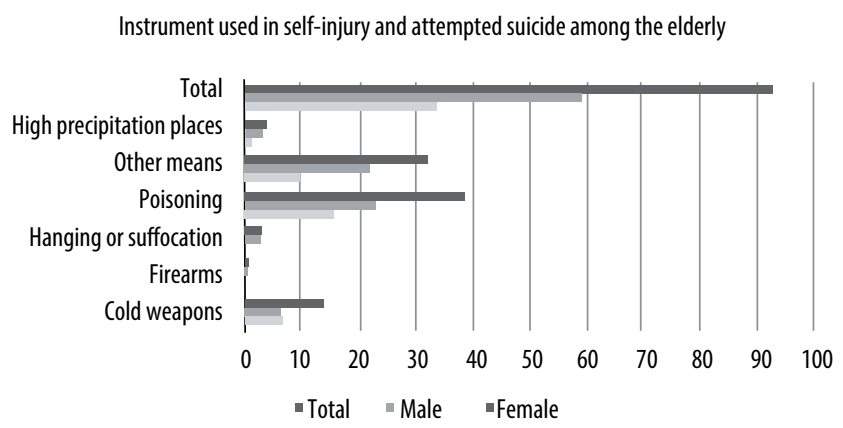

Figure 2. Notification of self-injury and attempted suicide among the elderly population living in the city of São Paulo, according to gender and the instrument used in 2014.

Regarding the place of occurrence, $52.7 \%$ occurred inside the elderly's own residence and the time of occurrence was 19.4\% during the day (morning and afternoon), 5.4\% during the night (night and dawn), and other data was ignored.

Diagnosis of injury, according to the International Chapter of IIIness (CID-10) fist and hand injuries represented (22.6\%), intoxication by drugs, medications and biological substances (22.6\%), toxic effects of substances of predominantly nonmedicinal origin (15.1\%).

According to the self-injury report and suicide attempt, the race/color of the elderly represented by $37.6 \%$ brown, 35.5\% white, $6.5 \%$ black, and $1.1 \%$ asian.

The education of the elderly presented $41.9 \%$ did not have elementary school finished (1 to 7 years), 5.4\% did not have any year of study, 5.4\% (8 to 11 years) and 4.3\% (12 years and more).

Self-injury and attempted suicide among elderly under the influence of alcohol corresponded $8.6 \%$ of reported cases.

In the analyzed period on evolution of reported cases of self-injury and attempted suicide among elderly received in the health services $67.7 \%$ were immediately discharged, $4.3 \%$ were already dead or died during care, 6.5\% hospitalization, $9.7 \%$ transferred to another service, $9.7 \%$ were under observation. It is worth mentioning that the unit of care was 45.2\% Ambulatory Medical Assistance (AMA), 33.3\% in Hospitals, 9.7\% in Basic Health Units (BHU), 5.4\% in Emergency Room, and 4,3\% in the Psychosocial Care Center (CAPS-Adult). 


\section{DISCUSSION}

In the present study, 93 reported cases of self-injury and attempted suicide among elderly residents in the city of São Paulo occurred in 2014, mainly in the South Region representing $40.9 \%$ of the cases. This fact may be associated with a largest population and a region where it is composed of more peripheral and low income neighborhoods, where a large part of the population is exclusively dependent on the Unified Health System (SUS).

Significant differences in social risk factors for suicide affecting young people, adults and the elderly are highlighted in literature. For the elderly who is the object of this study, the associated factors for self-injury and suicide attempt are: death of a loved one, especially of a spouse; Terminal illness with uncontrollable pain; Fear of prolonging life without dignity, bringing economic and emotional damages to relatives; Social isolation; Changes in social roles that gave them recognition or situations of physical or mental dependence, before which the elderly person feels humiliated ${ }^{6,7}$.

Minayo and Cavalcante ${ }^{6}$ have reported that financial problems, relationship difficulties, family arguments, social isolation and loneliness are the most frequent social reasons for suicide among elderly ${ }^{6}$.

Still on reported data of self-injury and suicide attempt, according to the region where the elderly resides, several factors may influence in search or not for a medical service, among them the potential risk of death, easy access and confidence in the Health System, as well as the existing stigma in relation to the suicide attempt. These factors, as mentioned will contribute to the construction of health services, and better qualification of health professionals to care of this elderly regarding the suicide attempts ${ }^{10,11}$.

Yet it is possible that part of health professionals resists meeting the demands understood by them as mental health in general hospitals, for example. It is believed that mental health professionals feel more mobilized and have a more positive attitude towards patients who attempted suicide than those who do not work in the area"1.

Regarding gender, it was observed a predominance of male elderly. Literature reports that women have more frequent suicidal behavior and more attempts made, being the most used method the ingestion of drugs and other toxic substances. This method is the most chosen because it is less invasive and, consequently, does not affect aesthetics. In the present study, $41.9 \%$ of the reported cases were due to poisoning/ intoxication, mainly due to ingestion of alcohol, and medication ${ }^{12,13}$.

Men commit more suicides and prefer methods that evidence their virility, using lethal means such as hanging, firearm and precipitation of high places ${ }^{13}$.
Table 1 showed that self-injury and suicide attempt occurred mainly among elderly men, with ages between 60 and 69 years. These data correlates with literature, due to high index at most advanced ages and increase in young adults. However, it is scarce in literature which portrays selfinjury and suicide attempt among elderly population ${ }^{13,14}$.

It is necessary for health professionals to recognize the signs and symptoms of patients with exogenous intoxication in a timely manner and to be prepared for the initial approach, as appropriate management will significantly influence inactivation of the toxicant, preventing complications and mortality ${ }^{15}$.

The use of domicile as a place for self-injury and suicide attempt (52.7\%), may suggest family de-structuring and conflicts, a frequent situation in homes of individuals that attempt against their own lives. Also as an important empowering factor, the recurrence of self-injury and attempted suicide among the elderly may have a positive return in terms of request for help and/ or change of environment, which would encourage the repetition of the act $^{16}$.

In this sense, it is necessary the development of strategies, especially in local health systems of welcoming and listening to these elderly people, helping on the recovery of their self-esteem and overcoming the stressor event. For this purpose, policies directed to aspects of the elderly's life are essential, since they direct the work of health professionals, besides guaranteeing legitimacy and visibility of this problem, often invisible in the eyes of society and of the family itself ${ }^{16}$. Self-injuries and suicide attempts occur mainly during the day, probably where the elderly develops their living daily activities. A limitation of this study was its inability to verify if the elderly ingested poison or medication by mistake, forgetfulness or confusion. As well as it was not possible to evaluate if the elderly population had any mental disorder and other comorbidities.

As far as diagnosis of injury is concerned, the instruments of suicide attempt, intoxication and poisoning, as well as intoxication by drugs, drugs and biological substances (22.6\%) were diagnosed.

The majority of the elderly who had suffered self-injury and attempted suicide had low education (41.9). Although, this is a little studied factor in the literature, previous studies have indicated a positive association between suicide rates and low educational level17. One possible explanation for this association is that the educational level, unemployment situation and family income, as well as the marital status, define the individual's economic and social status, which provides different levels of worry and stress ${ }^{17}$.

As in previous studies, a high suicide mortality rate was found in mixed race population, which dialogues to the present study, in which the race/brown elderly population 
(37.6\%) was found. The process of devaluation of AfroBrazilian Culture throughout history of Brazil, with exaltation of an increasingly technological and capitalist way of life, may have contributed to the increase of these reported cases ${ }^{17,18}$.

It is argued that because of the impossibility of retreating from Western civilization Africans were enslaved, but with no chance of occupational insertion and no guarantee of survival, and therefore marginalized. In the anthropological view the Afro descendants live a kind of "cultural death" added to an "absence of perspectives"18.

It is noteworthy, in the present study that for cases of selfinjury and attempted suicide among the elderly, one was due to alcohol and drug abuse. Drugs abuse and alcohol are one of the most serious social and health problems of our time, affecting the individual in its biopsychosocial dimension ${ }^{19}$.

Considering the social impact and health care costs of occurrences among elderly, whose number tends to increase in the next years in our country. It is necessary to better understand this type of occurrence, articulating this theme with the care of multi professionals acting in intersectoriality, nevertheless, considering that educational action and surveillance in health guiding axes for their professional performance ${ }^{19}$.

Regarding the evolution of cases, a large part of the elderly attended was discharged from health services. This is a limitation of this present study, because as the information system is based on the report card of suspected or confirmed cases of violence and accidents, the quality of filling is fundamental for formulating strategies. It is not possible to evaluate whether the elderly really had to leave the service or if they had been referred to other services.

It has shown the importance of the health teams working in hospitals, AMA, UBS in identification of suicidal behaviors and factors that exacerbate the risk of suicide, as well as the use of strategies for their prevention. He also highlighted the relevance of professional interventions among elderly who attempted suicide, in order to provide safety and trust to the patient, family, and health institution. Therefore, professionals must be qualified to perform necessary interventions to the patient seeking service and to provide the most appropriate referral in each case ${ }^{20}$.

The high rate of underreporting self-injury and suicide attempt is also reported in studies conducted in other regions, indicating the need to integrate existing information systems in the country21,22.

\section{CONCLUSIONS}

From the results of this study it was possible to characterize some specific aspects related to self-injury and suicide attempt among elderly in the evaluated population.
It has been found that most of the drugs used as a means for suicide, were mainly alcohol, poison, and psycho-actives.

It is considered necessary to turn a gaze upon the elderly population, in what concerns external causes for self-injury and suicide attempt. Therefore, developing a strategy to promote effective prevention actions and offer specialized services to most risk groups (brown races, people with lower levels of education, and males).

\section{INDIVIDUAL CONTRIBUTIONS}

Jane de Eston Armond - Contributed to work guidance.

Rodrigo de Eston Armond - Contributed to the collection of information.

Tatiana Cristina Pereira - Contributed to the review of content.

Cléo Chinaia - Contributed to the collection of information.

Thiago Leão Vendramini - Contributed to the bibliographical survey and revision of the content.

Cintia Leci Rodrigues - Contributed to the preparation of the manuscript.

\section{REFERENCES}

1. Alves DSB, Barbosa MTS, Caffarena ER, Silva AS. Caracterização do envelhecimento populacional no município do Rio de Janeiro: contribuições para políticas públicas sustentáveis. Cad Saúde Colet. 2016;24(1):63-9.

2. Porciúncula RCR, Carvalho EF, Barreto KML, Leite VMM. Perfil socioepidemiológico e autonomia de longevos em Recife-PE, Nordeste do Brasil. Rev Bras Geriatr Gerontol. 2014;17(2):315-25.

3. Joo Y. Spatiotemporal study of elderly suicide in Korea by age cohort. Public Health. 2017;142:144-51.

4. Özer E, Gümüs B, Balandiz H, Kirci GS, Aydogdu HI, Tetikçok R. Evaluation of geriatric suicides in Turkey. J Forensic Leg Med. 2016;44:158-16.

5. Vidal CEL, Contijo ECDM, Lima LA. Tentativas de suicídio: fatores prognósticos e estimativa do excesso de mortalidade. Cad Saúde Pública. 2013;29(1):175-87.

6. Minayo MCS, Cavalcante FG. Suicide in elderly people: a literature review. Rev Saúde Pública. 2010;44(4):1-7.

7. Silveira RE, Santos AS, Ferreira LA. Impacto da morbi-mortalidade e gastos com suicídio no Brasil de 1998 a 2007. Rev Pesqui Cuid Fundam. 2012;4(4):3033-42.

8. Secretaria Municipal da Saúde (SP). Portaria no 1328/07, de 28 de agosto de 2007. Implantar o "Sistema de Informação para a Vigilância de Violências e Acidentes - SIVVA", no Município de São Paulo. Diário Oficial do Município. 28 ago. 2007; Seção 159.

9. 9. São Paulo. Secretaria Municipal de Saúde. Sistema de Informação e Vigilância de Violências e Acidentes - SIVVA [Internet]. São Paulo: Prefeitura de São Paulo; Available from: http://www.prefeitura.sp.gov.br. Access on: Nov. 27, 2016.

10. Macchiaverni J, Borges LM, Oliveira LDB. Instrumento para registro de atendimento psicológico a tentativas de suicídio. Barbarói. 2013;39:129-48.

11. Freitas APA, Borges LM. Tentativas de suicídio e profissionais de saúde: significados possíveis. Estud Pesqui Psicol. 2014;14(2):560-77.

12. Almeida SA, Guedes PMM, Nogueira JA, França UM, Oliveira e Silva AC. Investigação de risco para tentativa de suicídio em hospital de João Pessoa - PB. Rev Eletr Enf. 2009;11(2):383-9. 
13. Magalhães APN, Alves VM, Comassetto I, Lima PC, Mancussi e Faro AC, Nardi AE. Atendimento a tentativas de suicídio por serviço de atenção pré-hospitalar. J Bras Psiquiatr. 2014;63(1):16-22.

14. Viana GN, Zenkner FM, Sakae TM, Escobar BT. Prevalência de suicídio no Sul do Brasil, 20012005. J Bras Psiquiatr. 2008;57(1):38-43.

15. Dantas JSS, Uchôa SL, Cavalcante TMC, Pennafort VPS, Caetano JA. Perfil do paciente com intoxicação exógena por "chumbinho" na abordagem inicial em serviço de emergência. Rev Eletr Enf. 2013;15(1):54-60.

16. Trevisan EPT, Santos JAT, Oliveira MLF. Suicide attempts in women: data from a toxicological assistance center in Parana. Rev Min Enferm. 2013;17(2):412-7.

17. Rios MA, Anjos KF, Meira SS, Nery AA, Casotti CA. Completude do sistema de informação sobre mortalidade por suicídio em idosos no estado da Bahia. J Bras Psiquiatr 2013;62(2):131-8.
18. Machado DB, Santos DN. Suicídio no Brasil, de 2000 a 2012. J Bras Psiquiatr. 2015;64(1): 45-54.

19. Reis LM, Martins BF, Gavioli A, Mathias TAF, Oliveira MLF. Men's health: hospital admissions for poisoning recorded in a toxicology treatment center. Esc Anna Nery. 2013;17(3):505-11.

20. Reisdorfer N, Araujo GM, Hildebrandt LM, Gewehr TR, Nardino J, Leite MT. Suicídio na voz de profissionais de enfermagem e estratégias de intervenção diante do comportamento suicida. Rev Enferm UFSM. 2015;5(2):295-304.

21. Rebelo FM, Caldas ED, Heliodoro V0, Rebelo RM. Intoxicação por agrotóxicos no Distrito Federal, Brasil, de 2004 a 2007 - Análise da notificação ao Centro de Informação e Assistência Toxicológica. Ciênc Saúde Coletiva. 2011;16(8):3493-502.

22. Braden JB, Edlund MJ, Sullivan MD. Suicide Deaths with Opioid Poisoning in the United States: 1999-2014. Am J Public Health. 2017;10(7):421-6. 